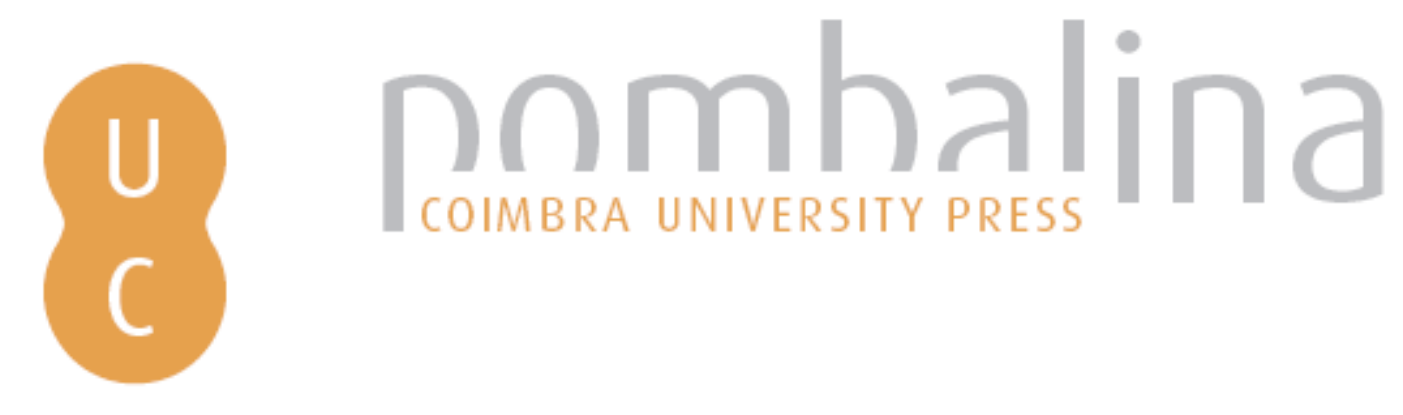

\title{
Generation of a global burned area product from satellite data: the ESA Fire_cci project
}
Autor(es):
Chuvieco, Emilio; Pettinari, M. Lucrecia; Lizundia-Loiola, Joshua; Roteta, Ekhi; Padilla Parellada, Marc; Oom, Duarte; Lewis, Philip; Storm, Thomas; Kaiser, Johannes; Mouillot, Florent; Laurent, Pierre; Bistinas, loanis

Publicado por: Imprensa da Universidade de Coimbra

URL persistente:

URI:http://hdl.handle.net/10316.2/44631

DOI:

DOI:https://doi.org/10.14195/978-989-26-16-506_114

Accessed : $\quad$ 26-Apr-2023 11:33:25

A navegação consulta e descarregamento dos títulos inseridos nas Bibliotecas Digitais UC Digitalis, UC Pombalina e UC Impactum, pressupõem a aceitação plena e sem reservas dos Termos e Condições de Uso destas Bibliotecas Digitais, disponíveis em https://digitalis.uc.pt/pt-pt/termos.

Conforme exposto nos referidos Termos e Condições de Uso, o descarregamento de títulos de acesso restrito requer uma licença válida de autorização devendo o utilizador aceder ao(s) documento(s) a partir de um endereço de IP da instituição detentora da supramencionada licença.

Ao utilizador é apenas permitido o descarregamento para uso pessoal, pelo que o emprego do(s) título(s) descarregado(s) para outro fim, designadamente comercial, carece de autorização do respetivo autor ou editor da obra.

Na medida em que todas as obras da UC Digitalis se encontram protegidas pelo Código do Direito de Autor e Direitos Conexos e demais legislação aplicável, toda a cópia, parcial ou total, deste documento, nos casos em que é legalmente admitida, deverá conter ou fazer-se acompanhar por este aviso.

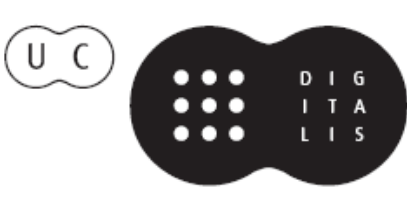




\section{ADVANCES IN}

\section{FOREST FIRE RESEARCH}

\section{8}

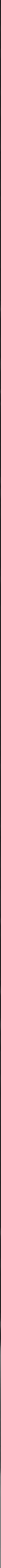




\title{
Generation of a global burned area product from satellite data: the ESA Fire_cci project
}

Emilio Chuvieco ${ }^{1 *}$; M. Lucrecia Pettinari ${ }^{1}$; Joshua Lizundia-Loiola ${ }^{1}$; Ekhi Roteta ${ }^{2}$; Marc Padilla Parellada $^{3}$; Duarte Oom ${ }^{4}$; Philip Lewis ${ }^{5}$; Thomas Storm ${ }^{6}$; Johannes Kaiser ${ }^{7}$; Florent Mouillot ${ }^{8}$; Pierre Laurent ${ }^{9}$; Ioanis Bistinas ${ }^{10}$

${ }^{1}$ Grupo de Investigación de Teledetección Ambiental, Universidad de Alcalá, Calle Colegios 2, 28803 - Alcalá de Henares, Spain.\{emilio.chuvieco@uah.es*, mlucrecia.pettinari@uah.es, joshua.lizundia@uah.es\}

${ }^{2}$ Universidad del País Vasco, Barrio Sarriena s/n, 48940 - Leioa, Spain. \{ekhi.roteta@ehu.eus\}

${ }^{3}$ Department of Geography, University of Leicester, University Road, Leicester, LE1 7RH, United Kingdom. \{mp489@leicester.ac.uk\}

${ }^{4}$ Instituto Superior de Agronomia, Universidade de Lisboa, Tapada da Ajuda

1349-017 Lisboa Portugal. \{duarte.oom@gmail.com\}

${ }^{5}$ Department of Geography, University College London, Gower St., London WC1H 6BT, United Kingdom.\{ucfalew@ucl.ac.uk\}

${ }^{6}$ Brockmann Consult GmbH, Max-Planck-Str. 2, 21502 - Geesthacht, Germany. \{thomas.storm@brockmann-consult.de\}

${ }^{7}$ Max Planck Institute for Chemistry, Hahn-Meitner-Weg 1, A.3.53, 55128-Mainz, Germany. \{j.kaiser@mpic.de\}

${ }^{8}$ Institut de Recherche pour le développement, CEFE/CNRS, Campus du CNRS, 1919 route de Mende, 34293 - Montpellier 5, France. \{florent.mouillot@cefe.cnrs.fr\}

${ }^{9}$ Laboratoire des Sciences du Climat et de l'Environnement, Bât. 12, Avenue de la Terrasse,F91198 GIF-SUR-YVETTE, France. \{pierre.laurent@lsce.ipsl.fr\}

${ }^{10}$ Faculty of Earth and Life Sciences, Vrije Universiteit Amsterdam, De Boelelaan 1105, 1081 HV Amsterdam,The Netherlands. \{i.bistinas@vu.nl\}

\begin{abstract}
Biomass burnings (including forest, grassland, peatland and agricultural fires) have important impacts on global terrestrial and atmospheric systems, affecting land cover, surface albedo, and the atmospheric concentration of greenhouse gases, chemically reactive species and aerosols. Several products have been generated in the last years to estimate total burned area, but uncertainties remain, particularly those associated to small and low intensity fires. Impact of climate and societal changes modify traditional fire regimes, extending fire seasons, increasing fire severity or introducing fire in sensitive areas.

The Fire_cci project of the European Space Agency Climate Change Initiative aims to generate consistent time series of burned area products to assess the extent of biomass burnings, as well as their spatial and temporal characteristics. Fire impacts on atmospheric and terrestrial processes are assessed, including modifications of vegetation patterns and biomass availability.

The global burned area products of the Fire_cci program currently available are derived from MERIS FRS and MODIS 250m sensors and cover the period from 2001 to 2016. These global burned area products are complemented with a small-fire database generated from medium resolution sensors (Sentinel-2 and Sentinel1) for the African continent. BA algorithms for new Sentinel-3 sensors (OLCI and SLSTR) are also being developed. Validation of the global products is based on a statistical sampling design of 1200 Landsat scenes.
\end{abstract}

Keywords: Burned area, Remote Sensing, Earth Observation, Global, Fire impacts, ESA, CCI 


\section{Introduction}

Fire has shaped human history from the very beginning. It has been used to cook, change vegetation composition, hunting and creating harder tools. Nowadays, fire is still used widely to transform land use, improve soil nutrients, help hunting, mining and other human activities (Bowman et al., 2013; Hantson et al., 2015). Current estimations show that 3.5-4 $\mathrm{Mkm}^{2}$ are burned every year (Alonso-Canas and Chuvieco, 2015; Giglio et al., 2013). Fire mainly affects tropical forests and savannas in Africa, Brazil and Indonesia, temperate forest and grasslands in USA, South America and Eurasia, and boreal forest in Siberia and N. America. Fire effects include impacts on atmospheric composition, carbon budgets and vegetation dynamics. Global estimates of fire emissions are between 1 and $3 \mathrm{Pg} \mathrm{C}$ year-1 (van der Werf et al., 2010). Fire reduces tree cover and in consequence the ability of terrestrial ecosystems to sequester carbon (Yue et al., 2014).

Even though the current understanding of climate-fire interactions is limited, there is also increasing evidence on their mutual influence (Hantson et al., 2015; Kloster et al., 2012; Yue et al., 2015). Climate has a strong influence on all aspects of the fire regime. It is related to seasonal timing temperature and humidity, as well as wind (that helps spreading the fire). Climate also influences the nature and availability of fuel, through its influence on the productivity and type of vegetation. Expected temperature (dryer vegetation conditions) and rainfall changes are likely to increase wildfire frequency in some regions, while others may experience decrease in fire activity as a result of decreased biomass production (Krawchuk et al., 2009). On the other hand, fires also affect climate. GHG and aerosol emissions, as well as albedo changes (from vegetation to soil) affect overall radiation budget, although their impacts are not yet well defined. For instance, the impact of increasing boreal forest fires on climate warming may be limited or even result in regional cooling because of the negative forcing from increased surface albedo following a fire (snow albedo is much higher than vegetation's). Climate modelling studies suggest that aerosols derived from burning may lengthen or intensify periods of drought in the Equatorial regions. The relevance of fires in the global terrestrial system has pushed the development of fire modules within Dynamic Global Vegetation Models (DGVM), such as the SPITFIRE (Yue et al., 2015).

The global impacts of fire justify a growing interest of deriving global burned area products. This is the basis of selecting Fire disturbance as one of the Essential Climate Variables (ECV) defined by the Global Climate Observing System (GCOS). These ECVs are intended to have a systematic and long-term record of observations that are relevant for climate modelling. Many of these variables can be systematically retrieved using different satellite Earth observation systems, and therefore GCOS has provided different guidelines for creating international programmes to generate those ECVs (GCOS, 2016).The European Space Agency (ESA) responded to this petition by creating the Climate Change Initiative (CCI) programme in 2010. The ESA CCI programme includes 13 variables, covering atmospheric, oceanic and land ECVs, which are systematically derived from up to date satellite sensors (Hollmann et al., 2013).

Fire disturbance (defined as the extent and characteristics of burned areas) was one of those variables included in the ESA CCI programme in 2010. Since then, the project teams have generated global databases of burned areas (BA), with the adequate auxiliary information to fit climate modellers' needs. This paper presents the main outputs of the Fire_cci project, including review of user needs, data generation, validation and assessment. In addition to global products, a small fire database (SFD) has been generated for Sub-Saharan Africa, which will not be covered in this manuscript. 


\section{Methods}

\subsection{User requirement analysis}

Since the main target community of the CCI programme are climate modellers, a survey was conducted to better understand user needs and prepare product specifications accordingly. The review of Mouillot et al. (2014) identified the main uses of BA products and the specific demands of modellers. This work was extended by dedicated questionnaires to different users of BA products, including carbon and atmospheric chemistry modellers, fire ecologists and civil protection services. As a result of the literature review and user interviews, several priorities for global BA products were identified:

(i) Long-term series data for understanding the long-term fire, climate and vegetation interaction. Temporal consistence should be assured within a 5\% threshold.

(ii) Temporal resolution should be daily data at the original spatial resolution of the sensor, weekly, 10-day or monthly basis on global scale.

(iii)Spatial resolution of the product should be 5-25 hectares for regional analysis and 0.25 to 0.5 degrees at global scale.

(iv)Maximum omission and commission errors should be below 15\%, with demonstrated systematic and adequate validation using internationally agreed validation protocols.

(v) Error traceability and uncertainty characterization should be included in both the pixel and grid products, in a manner that can be easily understood and utilized by users in various applications.

(vi)Easy access to data, including auxiliary information and metadata on burned cover, burn patch distribution and burn severity/efficiency.

\subsection{Product specifications}

Following recommendations from users, two sets of Fire_cci BA products were defined. They include pixel outputs (at the level of spatial detail of each sensor) and grid products (global summaries at coarser spatial resolution, which better fits climate models' resolution). Each product included a set of auxiliary variables to help the main user communities. They are:

- Pixel product: continental tiles of monthly BA, including three variables: date of burned, confidence level and land cover burned (extracted from the Land Cover CCI project, Kirches et al., 2013). The product is delivered in GeoTIFF format.

- Grid product at $0.25 \times 0.25$ degree resolution cells accumulating data every 15 days. It includes 23 layers: total burned area in the period, standard error, fraction of burnable area, fraction of observed area, number of fire patches, and total BA in each of 18 different land covers. These files are distributed in NetCDF-CF format.

Both data sets are supported by metadata provided as XML in the case of the pixel product and embedded in the NetCDF format for the grid product.

\subsection{Burned Area algorithm}

A set of BA algorithms have been developed within the Fire_cci project adapted to the different input sensors:

- Continental scale for the small fire database. They are based on Sentinel-1 radar (SAR), and Sentinel-2 MSI (optical) data.

- Global scale: MERIS (300 m) on board ENVISAT, MODIS (250m) on board TERRA and OLCI and SLSTR on board the Sentinel-3 satellite. This paper focuses on these datasets.

The MERIS BA algorithm combined temporal changes in near infrared (NIR) reflectance with location of active fires (Alonso-Canas y Chuvieco, 2015). A similar approach was followed for the 
MODIS sensor, in this case including only information from the highest resolution channels (250 $\mathrm{m})$, to complement current NASA BA products based on $500 \mathrm{~m}$ resolution data (Giglio et al., 2013). Both algorithms detect burned pixels in two phases. The first one aims to detect seed pixels (those more clearly burned), thus minimizing commission errors, while the second one applies a contextual criterion to discriminate the complete BA patch from the seed pixels, aiming to reduce omission errors.

Before the seed phase was carried out, a monthly composite of images was generated. The compositing criterion was based on selecting the nearest day to the closest hotspot of each pixel. This criterion tried to identify those days when the fire signal had the highest contrast from the background, avoiding clouds, cloud shadows and other artefacts.

Once the composite was created, the seed phase tried to identify the most clearly burned pixels. Since burned areas are very diverse worldwide and therefore the changes in reflectance may greatly vary among different ecosystems, the selection of seeds was guided by a regional-adapted statistical approach. Detection thresholds were established for each 10x10 degree tile and each monthly period based on the probability distribution function of the NIR reflectances of the pixels detected as active fires in that region and period. A criterion to maximize separability between the distribution functions of burned and unburned pixels was applied to establish a spatio-temporal threshold. This was complemented with other temporal change thresholds in NIR reflectances to further assure that pixels selected were actually burned. Once the seeds were detected, a contextual criterion was applied to extend the seeds to their neighbours that were likely to be burned as well. This region-growing process was based on the NIR values, and the change in red and NIR reflectance between the seed pixels and the surrounding ones. A similar approach was applied to the MODIS R and NIR channels, adapting several thresholds to better suit the MODIS sensor characteristics.

The BA algorithm was processed globally for both sensors. For MERIS full resolution images the time series made public includes the period from 2005 to 2011 (Chuvieco et al., 2016), while for MODIS images, the processed period spans from 2001 to 2016 (Chuvieco et al., 2018). Both BA products are made publicly available and freely downloadable (https://geogra.uah.es/fire_cci/ last accessed June, $4^{\text {th }}$ 2018).

\subsection{Validation}

The reference data used for the validation was derived from pairs of Landsat images consecutive in time, following CEOS Cal-Val guidelines (Boschetti et al., 2009). Reference fire perimeters were derived from a semi-automatic algorithm and revised visually by two interpreters. Final sampling included 1200 Landsat pairs following a stratified random sampling design (Padilla et al., 2017). Accuracy measurements were derived from the error matrix, obtained from the cross tabulation between product and reference maps: overall accuracy $(\mathrm{OA})$, commission error (CE) ratio, omission error (OE) ratio, Dice coefficient (DC), bias (B) and the relative bias (rel B), the last two referring to the trend towards under or overestimation of BA.

\section{Results}

\subsection{Spatial trends}

Figure 1 includes an example of the global BA datasets for 2016 based on the MODIS Fire_cci v5.0 product (called FireCCI50 for short). The most extensive burnings occurred in the Tropical regions, particularly in the African continent, followed by the Northern regions of Australia, Central Brazil, Venezuelan and Colombian Llanos, and Southeast Asia. A second belt of burned regions is noticeable in the temperate grasslands and croplands of central Asia, and Southeast USA. The boreal forests of Russia and Canada have also an important role in global biomass burnings. 


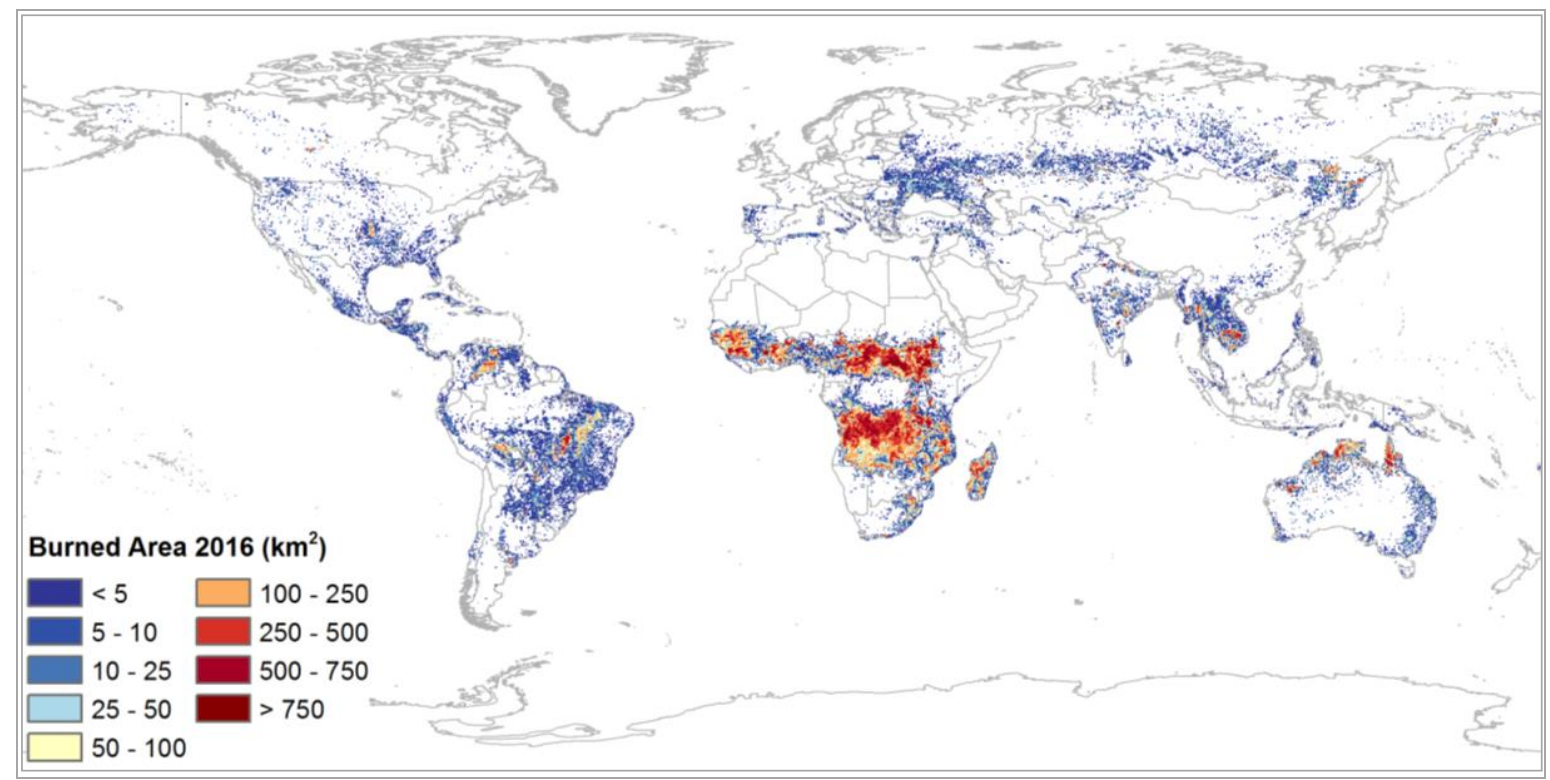

Figure 1 - Global Burned area of 2016 from FireCCI50

\subsection{Temporal trends}

Average yearly BA was $3.81 \mathrm{Mkm}^{2}$, approximately the size of India and France combined. Years with largest BA were 2004 and 2011 with more than $4.16 \mathrm{Mkm}^{2}$, while only 2013 and 2016 had less than $4 \mathrm{Mkm}^{2}$. These global trends are very similar to the GFED4, the most widely used BA database, which accounts for the same years an average total value of $3.38 \mathrm{Mkm}^{2}$, with yearly variations between 2.87 and $3.77 \mathrm{Mkm}^{2}$. Recent estimations from the MODIS BA product MCD64 c6 increase the estimations of our product by $15 \%$. Figure 2 shows the seasonal and multiyear cycle of burn activity comparing our results with the GFED4, MCD64 c6 and the MERIS Fire_cci v4.1 (FireCCI41) BA databases.

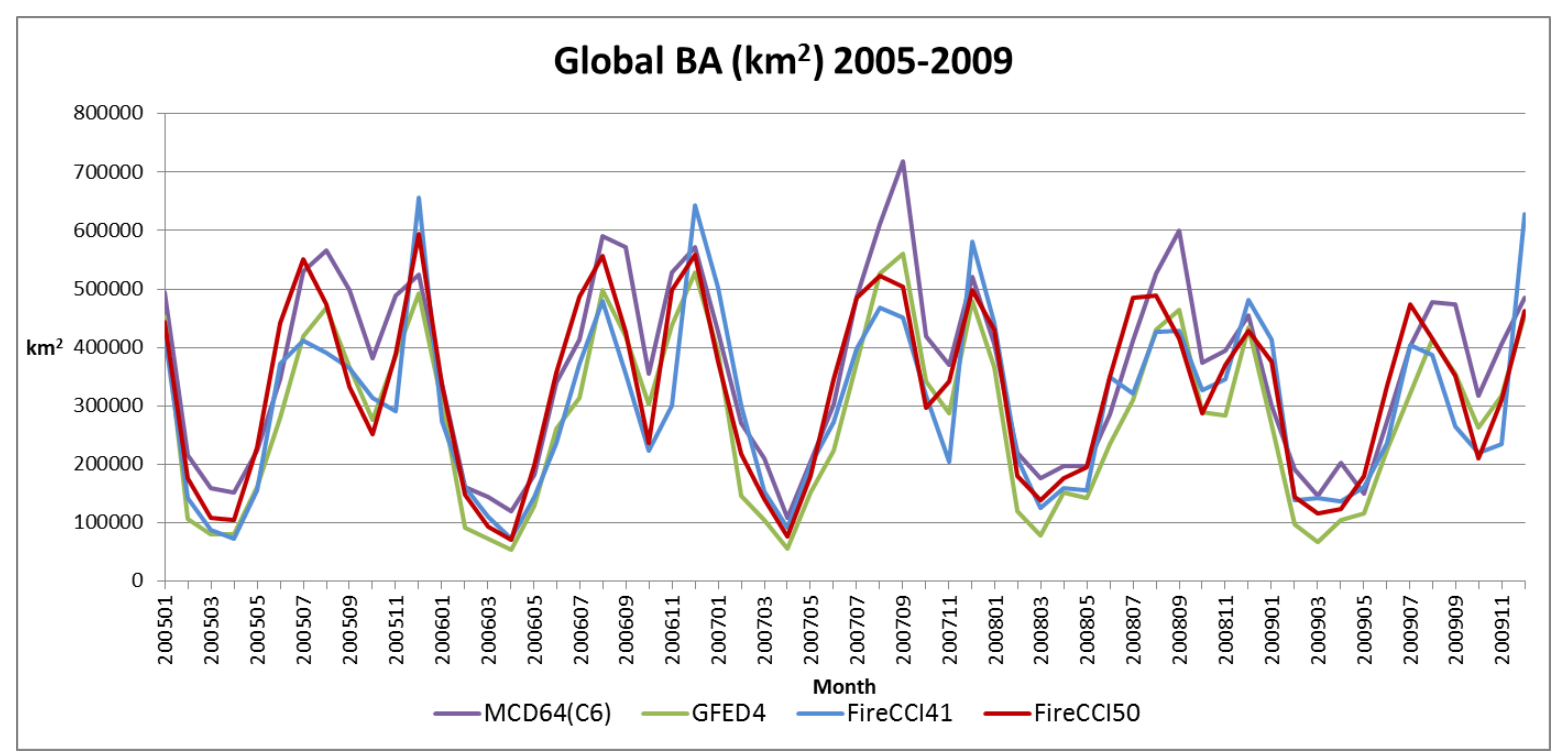

Figure 2 - Temporal trends of burn area in different global BA products

A clear seasonal pattern is observed throughout the years, with two peaks. The first one is located in December-January, which corresponded mainly to the dry season of the Northern Hemisphere (tropical burnings of Sub-Saharan Africa, Northern Australia, SE Asia, Central America and Northern fringe of South America). The second occurred in July-September and referred to the burnings of the Southern Hemisphere tropical regions of Africa and South America, the grasslands and agricultural 
burnings of South Asia, the temperate forest burnings of the Mediterranean, USA and Australia, and the Boreal regions of Canada, Russia and Alaska. The four BA databases agreed quite well, although MCD64 provided generally higher values. The GFED4 product, based on MODIS images, and the Fire_cci products showed similar trends, with a tendency to overestimate BA in the peak of DecemberFebruary in the case of the FireCCI41 product.

\subsection{Spatio-temporal patterns of the pixel product}

Figure 3 illustrates an example of the pixel products generated from the FireCCI50 dataset. It includes the date of detection and provides a much higher resolution than the grid product to analyse spatial and temporal patterns.

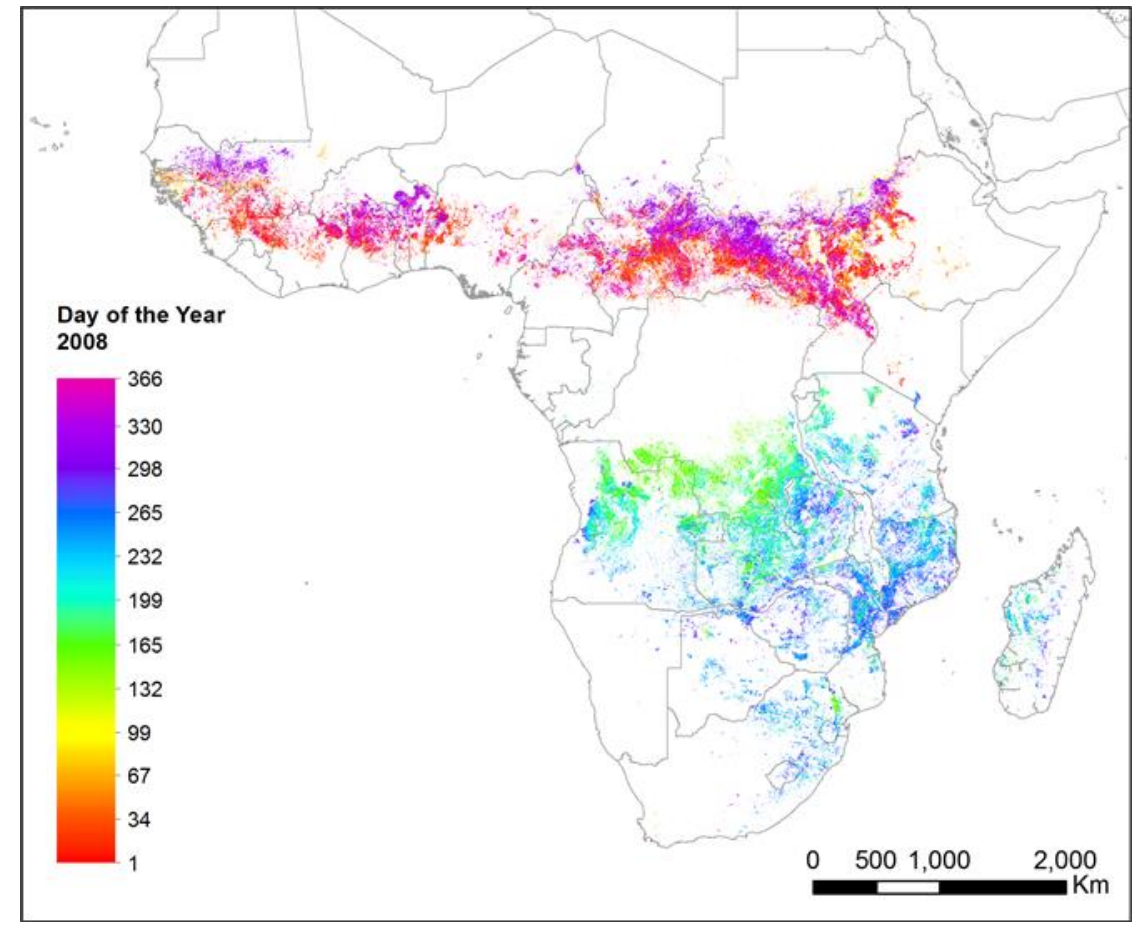

Figure 3 - Day of detection for Sub-Saharan Africa for the year 2008.

As it may be expected, two parallel fringes are observed, one in the Northern Hemisphere Tropical belt (Senegal, Ivory Coast, Ghana, Nigeria, Cameroun, Central African Republic, Chad and Sudan), mostly burned at the beginning or end of the year, in coincidence with the dry season of the Northern Hemisphere Tropics, and another one to the South of Equator, where a dry season occurs between June and September. Angola, Zambia, Zimbabwe, South Africa, Mozambique, Madagascar and Tanzania are the most affected countries in this latter region. Pixel products can be used for different objectives, both at global and regional scales. The Fire_cci pixel product has been used to analyse burn shapes (Chuvieco et al., 2018; Chuvieco et al., 2016), which is an interesting variable to better understand fire propagation patterns.

\subsection{Validation}

At global scale and for the time period with available data, the accuracy of FireCCI50 expressed by the Dice coefficient $(\mathrm{DC})$ was 0.365 (standard error $=0.026$ ). This value is significantly higher than for the FireCCI41 product ( $\mathrm{DC}=0.248$ with $\mathrm{SE}=0.030$ ), but lower than for the MCD64A1 c6 product ( $\mathrm{DC}=0.478$ with $\mathrm{SE}=0.031$ ). Similarly this is expressed by the commission and omission error ratios (Ce and Oe), $0.512(0.020)$ and $0.708(0.30)$ for FireCCI50, $0.643(0.045)$ and 0.810 (0.030) for FireCCI41, and $0.353(0.016)$ and $0.622(0.038)$ for MCD64A1 c6 respectively. FireCCI50 underestimates a fraction of $0.402(0.058)$ of the BA reported in the reference data, as expressed by 
the relative bias (relB), slightly less than MCD64A1 c6, 0.415 (0.056), and lower than FireCCI41, with a vaule of $0.468(0.094)$.

We should point out that these errors are most likely inflated, as they do not take into account reporting accuracy inaccuracies. This means that pixels correctly classified as burned may be labelled as omission errors when detected after the reference date of the Landsat multitemporal pairs used for generating reference files. Similarly, pixels correctly detected as burned but labelled a few days after the beginning of the Landsat multitemporal pair may be considered as commission errors. To analyse these impacts, three large areas (around 250,000 $\mathrm{km}^{2}$ ) were selected in Australia, Canada and California from where national fire perimeters were available. The omission and commission errors for these sites were much lower than those observed for the global sample (commission 0.22 to 0.4 and omission 0.35 to 0.5 ) for the FireCCI50 product.

\section{Conclusions}

This paper has shown results provided by the Fire_cci project, included in the Climate Change Initiative programme of the European Space Agency. The first assessment of these results provides coherent spatial and temporal trends, with similar patterns as the most widely used global BA products. Preliminary validation shows a high overall accuracy, but also high omission and commission errors of the burned class, which should partially be related to the temporal reporting accuracy and the impact of small fires in some regions.

\section{Acknowledgments}

The Fire_cci project is funded by the European Space Agency (ESA) as part of the Climate Change Initiative Programme.

\section{References}

Alonso-Canas I, Chuvieco E (2015) Global Burned Area Mapping from ENVISAT-MERIS data. Remote Sensing of Environment 163, 140-152.

Boschetti L, Roy DP, Justice CO (2009) International Global Burned Area Satellite Product Validation Protocol. Part I - production and standardization of validation reference data. http://lpvs.gsfc.nasa.gov/DOC/protocol_revised_Apr09.doc.

Bowman DM, O'Brien JA, Goldammer JG (2013) Pyrogeography and the global quest for sustainable fire management. Annual Review of Environment and Resources 38, 57-80.

Chuvieco E, Lizundia-Loiola J, Pettinari ML, Ramo R, Padilla M, Tansey K, Mouillot F, Laurent P, Storm T, Heil A, Plummer S (2018) Generation and analysis of a new global burned area product based on MODIS 250m reflectance bands and thermal anomalies. Earth System Science Data Discussion, https://doi.org/10.5194/essd-2018-46.

Chuvieco E, Yue C, Heil A, Mouillot F, Alonso-Canas I, Padilla M, Pereira JMC, Oom D, Tansey K. (2016) A new global burned area product for climate assessment of fire impacts. Global Ecology and Biogeography 25, 619-629.

GCOS (2016) The Global Observing System for Climate: Implementation Needs, GCOS-200. World Meteorological Organization. (Geneva, Switzerland)

Giglio L, Randerson JT, van der Werf GR (2013) Analysis of daily, monthly, and annual burned area using the fourth generation global fire emissions database (GFED4). Journal of Geophysical Research: Biogeosciences 118, 317-328. 
Hantson S, Pueyo S, Chuvieco E (2015) Global fire size distribution is driven by human impact and climate. Global Ecology and Biogeography 24, 77-86.

Hollmann R, Merchant CJ, Saunders R, Downy C, Buchwitz M, Cazenave A, Chuvieco E, Defourny P, de Leeuw G, Forsberg R, Holzer-Popp T, Paul F, Sandven S, Sathyendranath S, van Roozendael M, Wagner W (2013) The ESA Climate Change Initiative: satellite data records for essential climate variables. Bulletin of the American Meteorological Society 94, 1541-1552.

Kirches G, Krueger O, Boettcher M, Bontemps S, Lamarche C, Verheggen A, Lembrée C, Radoux J, Defourny P (2013) Land Cover CCI: Algorithm Theoretical Basis Document Version 2. Land_Cover_CCI_ATBDv2_2.3. (Louvain, Belgium).

Kloster S, Mahowald N, Randerson J, Lawrence P (2012) The impacts of climate, land use, and demography on fires during the 21st century simulated by CLM-CN. Biogeosciences 9, 509-525.

Krawchuk MA, Moritz MA, Parisien M-A, Van Dorn J, Hayhoe K (2009) Global Pyrogeography: the Current and Future Distribution of Wildfire. PLoS ONE 4, e5102.

Mouillot F, Schultz MG, Yue C, Cadule P, Tansey K, Ciais P, Chuvieco E (2014) Ten years of global burned area products from spaceborne remote sensing - A review: Analysis of user needs and recommendations for future developments. International Journal of Applied Earth Observation and Geoinformation 26, 64-79.

Padilla M, Olofsson P, Stehman SV, Tansey K, Chuvieco E (2017) Stratification and sample allocation for reference burned area data. Remote Sensing of Environment 203, 240-255.

van der Werf GR, Randerson JT, Giglio L, Collatz GJ, Mu M, Kasibhatla PS, Morton DC, DeFries RS, Jin Y, van Leeuwen TT (2010) Global fire emissions and the contribution of deforestation, savanna, forest, agricultural, and peat fires (1997-2009). Atmospheric Chemistry and Physics 10, $11707-11735$.

Yue C, Ciais P, Cadule P, Thonicke K, Archibald S, Poulter B, Hao WM, Hantson S, Mouillot F, Friedlingstein P, Maignan F, Viovy N (2014) Modelling the role of fires in the terrestrial carbon balance by incorporating SPITFIRE into the global vegetation model ORCHIDEE-Part 1: simulating historical global burned area and fire regimes. Geoscientific Model Development 7, 2747-2767.

Yue C, Ciais P, Cadule P, Thonicke K, van Leeuwen TT (2015) Modelling the role of fires in the terrestrial carbon balance by incorporating SPITFIRE into the global vegetation model ORCHIDEE - Part 2: Carbon emissions and the role of fires in the global carbon balance. Geoscientific Model Development 8, 1321-1338. 